\title{
Soybean chlorotic spot virus, a novel begomovirus infecting soybean in Brazil
}

\author{
Daniela Coco · Iara P. Calil · Otavio J. B. Brustolini • \\ Anesia A. Santos • Alice K. Inoue-Nagata • \\ Elizabeth P. B. Fontes
}

Received: 20 June 2012/ Accepted: 25 August 2012/Published online: 10 October 2012

(C) Springer-Verlag Wien 2012

\begin{abstract}
A novel soybean-infecting begomovirus from Brazil was identified in Jaíba, in the state of Minas Gerais, and molecularly characterized. By using rolling-circle amplification-based cloning of viral DNAs, three DNA-A variants and a cognate DNA-B were isolated from infected samples. The DNA variants share more than $98 \%$ sequence identity but have less than $89 \%$ identity to other reported begomovirus, the limit for demarcation of new species. In a phylogenetic analysis, both DNA-A and DNA-B clustered with other Brazilian begomoviruses. Infectious cloned DNA-A and DNA-B components induced distinct symptoms in Solanaceae and Fabaceae species by biolistic inoculation. In soybean, the virus induced mild symptoms, i.e., chlorotic spots on the leaves, from which the name soybean chlorotic spot virus (SoCSV) was proposed. The most severe symptoms were displayed by common beans, which exhibited leaf distortion, blistering, interveinal chlorosis, mosaic and golden mosaic.
\end{abstract}

Electronic supplementary material The online version of this article (doi:10.1007/s00705-012-1499-0) contains supplementary material, which is available to authorized users.

D. Coco · I. P. Calil · O. J. B. Brustolini .

A. A. Santos - E. P. B. Fontes $(\square)$

Departamento de Bioquimica e Biologia Molecular,

Universidade Federal de Vicosa, Vicosa, Brazil

e-mail: bbfontes@ufv.br

D. Coco · I. P. Calil · O. J. B. Brustolini ·

A. A. Santos - A. K. Inoue-Nagata - E. P. B. Fontes

National Institute of Science and Technology in Plant-Pest Interactions, Universidade Federal de Vicosa, Bioagro, Vicosa, MG 36570-000, Brazil

\author{
A. K. Inoue-Nagata \\ Embrapa Vegetables, Brasília, DF 70359-970, Brazil
}

The possibility that SoCSV may become a threat to bean production in Brazil is discussed.

The genus Begomovirus (family Geminiviridae) includes viruses with mono- or bipartite ssDNA genomes that are transmitted to dicotyledonous plants by the whitefly Bemisia tabaci $[10,16]$. Typically, the native begomoviruses from the Americas have two genomic components, DNA-A and DNA-B. DNA-A encodes the proteins that are required for replication (Rep and REn), the transcriptional activation of viral genes (TrAP), encapsidation (CP) and the suppression of RNAi defense functions (TrAP and AC4) $[16,19,20]$. The genes on DNA-B are required for the intra-(NSP) and intercellular (MP) movement of viral DNA-A and DNA-B [16]. NSP also functions as a virulence factor to suppress innate plant defenses $[9,17]$.

Collectively, the begomoviruses infect a large variety of relevant crops and cause major agricultural losses worldwide. In Brazil, the tomato- and bean-infecting begomoviruses severely impact crop productivity and are widely distributed throughout Brazil [4]. In contrast, soybeaninfecting begomoviruses have been reported only sporadically, and these viruses have not been associated with yield losses [7, 12]. However, with the recent report of soybeaninfecting begomoviruses causing moderate to severe losses in the neighboring country Argentina [15], there is concern that begomovirus infection in soybean may increase in Brazil. This potential threat to the sustainable agriculture of soybean in Brazil has intensified the surveys for begomovirus infection in the major soybean-producing areas. In this report, we describe the identification of a new soybeaninfecting begomovirus, designated soybean chlorotic spot virus (SoCSV), which, nevertheless, was found in symptomatic (chlorotic spots) leaves from two soybean plants 
(samples 9253 and 9254) grown in a tomato field in Jaíba, in the state of Minas Gerais, Brazil. They were spontaneously growing plants, probably from a previous cultivation.

Total DNA extracts from leaves of both infected soybean plants were subjected to full-length viral genome amplification using phage $\phi 29$ DNA polymerase, as described [11]. The 2.6-kb amplified fragments were cloned into pBluescript II KS + (Stratagene) and sequenced. The resulting clone, pUFV1588, harbors a full-length DNA-B, whereas the clones pUFV1587, pUFV1871 and pUFV1872 are genetic variants of DNA-A. Among them, the DNA-A variants were $98 \%$ identical and displayed a DNA-A genomic organization typical of bipartite begomoviruses, with five ORFs (Rep, TrAP, REn, CP and AC4). The DNAB plasmid, pUFV1588, harbored genes homologous to NSP and MP. The common region of SoCSV is highly conserved between the DNA-B and DNA-A variants pUFV1587 (94\% sequence identity, SI), pUFV1872 (93\% SI) and pUFV1873 (90\% SI) over a region of 172 nucleotides (Fig. S1). For both viral components, the intergenic region separating the divergent transcription units contained functional elements representing the geminivirus origin of replication, such as the conserved 30-bp stem-loop structure (Fig. S1) and the conserved TAATATTAC nonanucleotide sequence (Fig. S1), which contains the nicking site for initiation of virion-sense DNA replication [10]. As cognate DNA-A and DNA-B components, in addition to having a highly conserved common region, pUFV1587 (DNA-A) and pUFV1588 (DNA-B) share identical directly repeated iterons (GGTGA) separated by three nucleotides (ATT) upstream of the Rep gene TATA box, which is the putative Rep-binding site for the origin-specific recognition of New World begomoviruses [2, 3, 8, 13]. The putative binding site for Rep on SoCSV resembles the repeated iterons of other leguminous crop- and weed-infecting begomoviruses found in Brazil, such as bean golden mosaic virus (BGMV; GGTGY), Macroptilium yellow spot virus (MaYSV; GGTGT), Macroptilium yellow vein virus (MaYVV; GGTGY) and Macroptilium yellow net virus (MaYNV; GGTGN). The presence of the iteron consensus sequence GGTGA/Y in the common region of legume-infecting begomoviruses for Rep-specific recognition of replication origins may hold the potential for driving genetic reassortment in multiple infections.

Among begomoviruses, the SoCSV DNA-A nucleotide sequence was most closely related to that of MaYSV ( $85 \%$ SI), whereas the DNA-B shared the most sequence conservation with BGMV (67\% SI). This level of nucleotide sequence conservation (DNA-A less than $89 \%$ identity to known begomoviruses) is considered sufficiently dissimilar to define a distinct virus [6]. Therefore, the soybean isolate was assigned as a member of a new species of begomovirus, designated "Soybean chlorotic spot virus" (SoCSV;
GenBank accession numbers JX122965 for DNA-A and JX122966 for DNA-B), based on the symptomatology of the natural host from which the virus was obtained.

Phylogenetic analysis based on the nucleotide sequence of the SoCSV DNA-A and DNA-B and other begomoviruses from the Americas confirmed a geographical-originbased relatedness of the novel viral components (Fig. 1). The DNA-A was inserted into a cluster of Brazilian begomoviruses under a sub-branch of leguminous-hostinfecting viruses, which included BGMV, two leguminousweed-infecting viruses (MaYSV and Macroptilium yellow vein virus, MaYVV) that were recently detected in Northeastern Brazil [18], and Blainvillea yellow spot virus (BIYSV), which was recently identified in Southeastern Brazil. The DNA-B also grouped with mostly Brazilian viruses, forming a highly stable sub-branch $(100 \%$ bootstrap support) with BGMV and cleome leaf crumple virus $(\mathrm{ClLCrV})$, which was recently identified in Northeastern Brazil [14].

To determine the experimental host range properties of this novel begomovirus, we constructed infectious DNA-A and DNA-B recombinant plasmids harboring partial tandem repeats of the A and B components of SoCSV. The plasmids pUFV1587 and pUFV1588, which contain single copies of DNA-A and DNA-B, respectively, were used to subclone fragments that included the SoCSV-A or B common region and flanking sequences into pBluescript II $\mathrm{KS}+$. The resulting subclone pUFV1589 contains the 0.5 $\mathrm{kb}$ SacI/XbaI fragment (0.2-mer) from pUFV1587, whereas pUFV1590 harbors the $0.8-\mathrm{kb}$ SacI/EcoRV fragment (0.3-mer) from pUFV1588. Partial tandem copies of SoCSV DNA-A and DNA-B were constructed by inserting the SacI fragment (1-mer) from pUFV1587 into SacIdigested pUFV1589 and the Sac I fragment (1-mer) from pUFV1588 into SacI-digested pUFV1590. The resulting plasmids pSCS1.2A (pUFV1591) and pSCS1.3B (pUFV1592) contained 1.2 copies of SoCSV DNA-A and 1.3 copies of DNA-B, respectively, and had duplicated common regions.

The clones pSCS1.2A and pSCS1.3B were used for the biolistic inoculation of plants from the families Solanaceae (Nicotiana rustica, $N$. benthamiana, $N$. clevelandii, $N$. debneyi, N. glutinosa, N. tabacum, Solanum lycopersicum 'Santa Clara' and 'Rutgers', Capsicum annuum 'Casca Dura Ikeda'), Fabaceae (Glycine max 'Conquista' and “Msoy7908 RR”, Phaseolus vulgaris 'Pérola' and 'Ouro Negro') and Chenopodiaceae (Chenopodium quinoa). For the biolistic delivery of viral DNAs, DNA-coated tungsten particles were spread onto macrocarrier discs $(24 \mathrm{~mm}$ and $15.2 \mathrm{~mm}$, Bio-Rad), and inoculations of five-week-old seedlings (Solanaceae and Chenopodiaceae species) or emerging radicles (Fabaceae species) were performed using a non-commercially constructed PDS-1000/He-like 


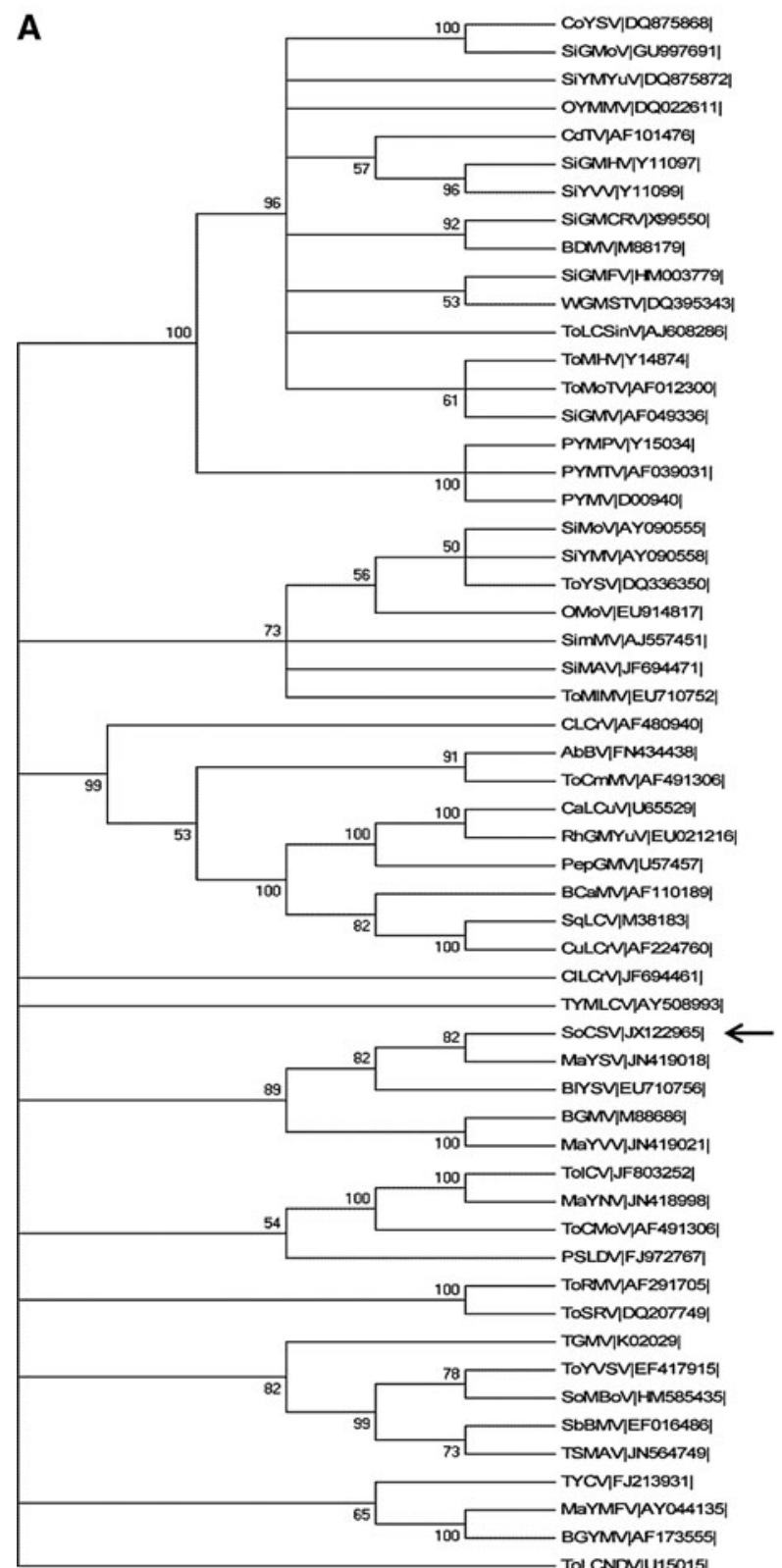

Fig. 1 Phylogenetic tree based on the alignment of the complete genome, DNA-A (a) and DNA-B (b) of SoCSV and selected begomoviruses from the Americas and the Old World. The trees were constructed by the neighbor-joining method using Mega 5.0 with 100,000 bootstrap replicates. The numbers shown at the nodes indicate the percentage bootstrap scores. SoCSV DNA-A and DNA-B are indicated by arrows. The DNA-A tree was rooted using tomato

accelerator at 900 psi. In each experiment, seven plants of each species were inoculated with $2 \mu \mathrm{g}$ of tandemly repeated DNA-A plus DNA-B per plant and grown in a greenhouse under natural conditions of light. Inoculated plants were sampled between 14 and 21 days post-inoculation (DPI). Total DNA was extracted from the systemically infected leaves (young), and viral DNA was detected

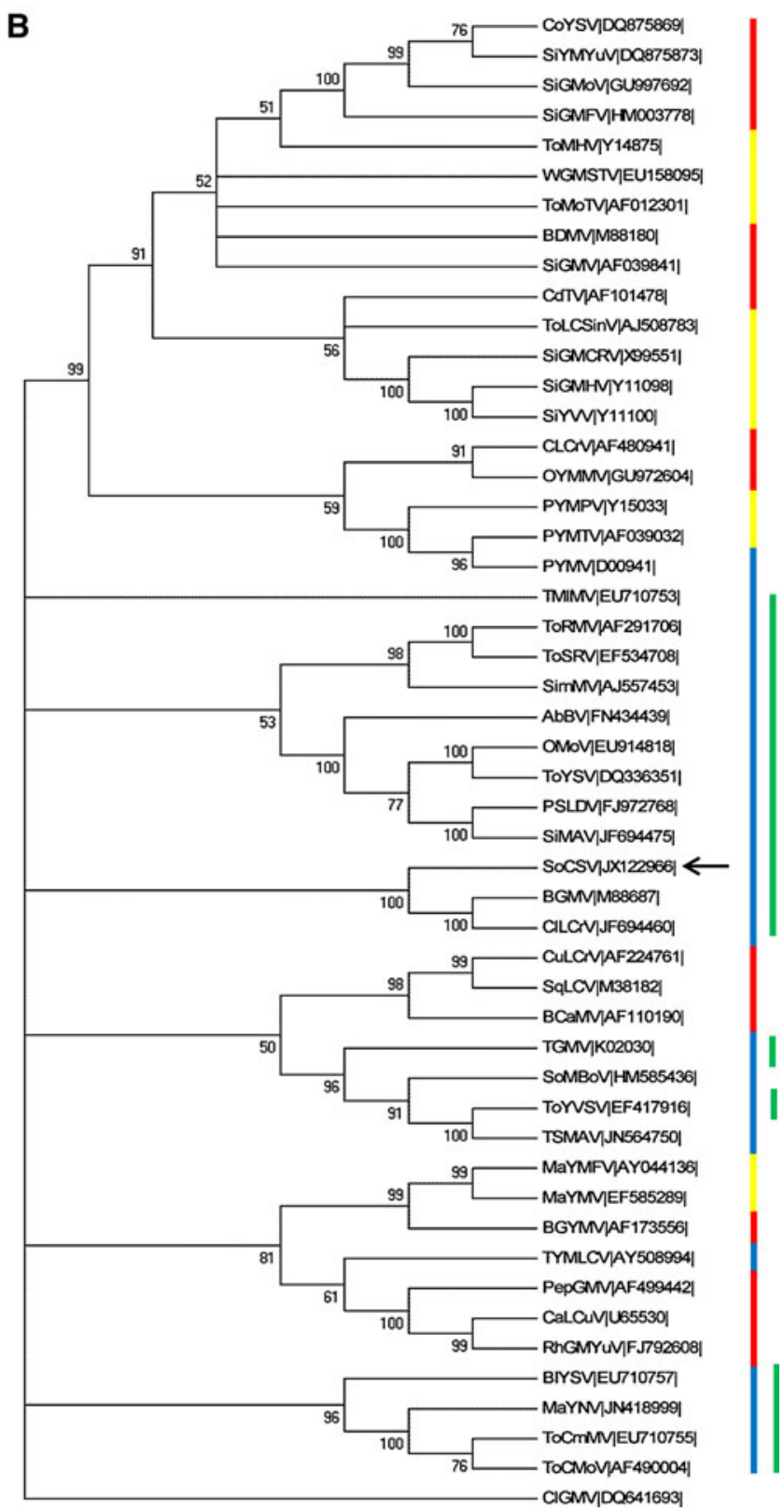

leaf curl New Delhi virus (ToLCNDV, U15015) as an outgroup. For the DNA-B tree, Clerodendrum golden mosaic virus (ClGMV, DQ641693) was used as an outgroup. Red bars delimit virus found in North America; yellow bars, Central America; blue bars, South America; and green bars, Brazil. Virus acronyms and GenBank accession numbers are shown in Table S1

by PCR with the SoCSV DNA-A-specific primers SoCSVNcoI-R (GGAGCCATGGGCTCCTCCGTTTC) and SoCSV-F (CAATAATAATGCGTTTTCCG). The results of the host-range test are displayed in Table 1.

SoCSV infected all of the tested species of the family Solanaceae except for S. lycopersicum 'Santa Clara' and 'Rutgers'. It also infected all of the tested species of the 
Table 1 Host range of SoCSV infectious clones

\begin{tabular}{|c|c|c|}
\hline Plant species & $\begin{array}{l}\text { Plants infected/inoculated (no. } \\
\text { of experiments) }\end{array}$ & Symptoms \\
\hline Capsicum аппиит & $7 / 7(1)$ & Mild interveinal chlorosis \\
\hline Chenopodium quinoa & $0 / 7(1)$ & - \\
\hline $\begin{array}{l}\text { Glycine max } \\
\text { 'Conquista' }\end{array}$ & $7 / 7(3)$ & Chlorotic spots \\
\hline $\begin{array}{l}\text { Glycine max } \\
\text { 'Msoy7908 RR' }\end{array}$ & $7 / 7(1)$ & Chlorotic spots \\
\hline Nicotiana benthamiana & $7 / 7(1)$ & Interveinal chlorosis \\
\hline N. clevelandii & $5 / 7(1)$ & - \\
\hline N. debneyi & $7 / 7(1)$ & Interveinal chlorosis \\
\hline$N$. glutinosa & $7 / 7(1)$ & - \\
\hline N. tabacum & $6 / 7(1)$ & - \\
\hline N. rustica & $6 / 7(1)$ & Interveinal chlorosis \\
\hline $\begin{array}{l}\text { Solanum lycopersicum } \\
\text { 'Rutgers' }\end{array}$ & $0 / 7(2)$ & - \\
\hline $\begin{array}{l}\text { Solanum lycopersicum } \\
\text { 'Santa Clara' }\end{array}$ & $0 / 7(2)$ & - \\
\hline $\begin{array}{l}\text { Phaseolus vulgaris } \\
\text { 'Ouro Negro' }\end{array}$ & $6 / 7(3)$ & $\begin{array}{l}\text { Leaf distortion, blistering, interveinal } \\
\text { chlorosis, mosaic, golden mosaic }\end{array}$ \\
\hline $\begin{array}{l}\text { Phaseolus vulgaris } \\
\text { 'Pérola' }\end{array}$ & $5 / 7(3)$ & $\begin{array}{l}\text { Leaf distortion, blistering, interveinal } \\
\text { chlorosis, mosaic, golden mosaic }\end{array}$ \\
\hline
\end{tabular}

family Fabaceae. Although we detected viral DNA accumulation in newly emerging, systemic leaves of $N$. clevelandii, N. tabacum and N. glutinosa at $21 \mathrm{DPI}$, no visible symptoms were observed in these permissive hosts (data not shown). The infected $C$. annuum, $N$. benthamiana, $N$. debneyi, N. Rustica (Fig. S2), G. max "Conquista" and G. max "Msoy 7908 RR" plants displayed mild symptoms (Fig. 2a and $b$, described in Table 1). The most-severe symptoms were observed in $P$. vulgaris 'Pérola' and $P$. vulgaris 'Ouro Negro', which exhibited leaf distortion, blistering, interveinal chlorosis, mosaic and golden mosaic (Fig. 2c, d, e and f). Therefore, under our experimental conditions and based on symptomatology, SoCSV seems to be more pathogenic to the experimental host bean than to soybean.

The discrepancy in the severity of SoCSV-induced symptoms in soybean and common bean resembles that seen with BGMV infection, which causes severe symptoms in $P$. vulgaris and represents a serious constraint on bean production in Brazil but produces attenuated symptoms in G. max and does not limit soybean productivity [7]. However, in spite of the apparent higher pathogenicity of SoCSV to beans and unlike BGMV, the virus has not been found infecting beans, in the field. Particularly, in Brazil, only BGMV has been found in common beans. In fact, a survey conducted in the major bean-producing regions of seven different states in Brazil revealed the dominance of BGMV in the collected samples [5]. This scenario is not likely to have changed since then; a recent circomics study revealed that only BGMV and intra-species genetic variants $(99.7 \% \mathrm{SI})$ were found in infected bean samples collected in Northeastern Brazil [21], a region in which distinct begomoviruses infecting leguminous weeds were identified [18]. The prevalence of BGMV in bean samples from a region in which the virus co-exists with other leguminous weed-infecting begomoviruses may indicate that the low diversity of bean-infecting begomoviruses is due to the absence of resistant bean cultivars that could drive the selective pressure towards the emergence of more-pathogenic species. If this is the case, an increase in the genetic variability of bean-infecting begomoviruses is expected to occur with the introduction of transgenic beans that are immune to BGMV to Brazil [1]. The identification of the novel soybean-infecting begomovirus SoCSV, which apparently can adapt to beans, supports the prediction that opportunistic infection of preexistent pathogenic begomoviruses may become a threat to BGMV-resistant transgenic beans.

The current investigation adds a new virus to the growing list of soybean-infecting begomoviruses found in Brazil [7, 12]. All of these viruses were identified in a relatively small sample of infected soybean leaves, suggesting that, in contrast to beans, soybeans may host a large diversity of begomoviruses. Therefore, the hypothesis that soybean can host multiple infections, which can then drive the emergence of more viruses that are pathogenic and virulent, with the capacity to infect both beans and soybeans, cannot be discarded in the Brazilian agricultural scenario. The recent release of transgenic bean lines that are immune to BGMV for field cultivation in Brazil may accelerate this evolutionary process. 


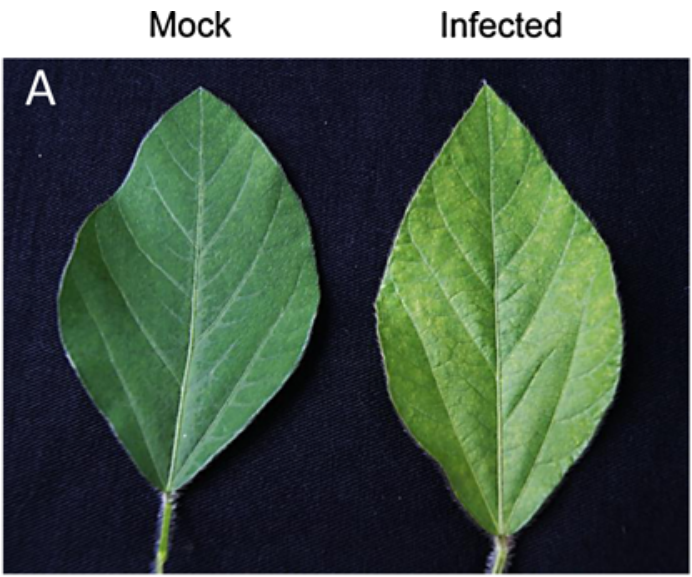

Mock

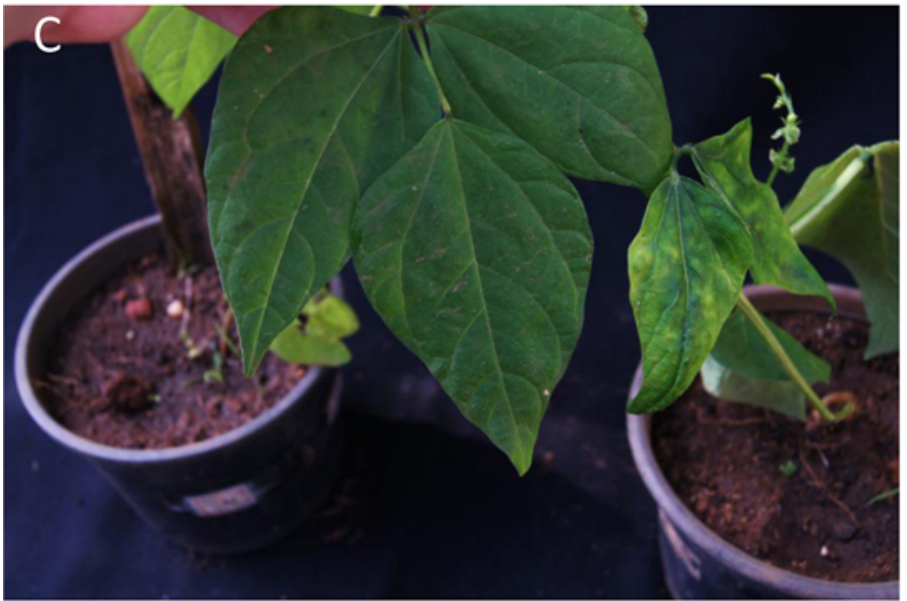

Mock

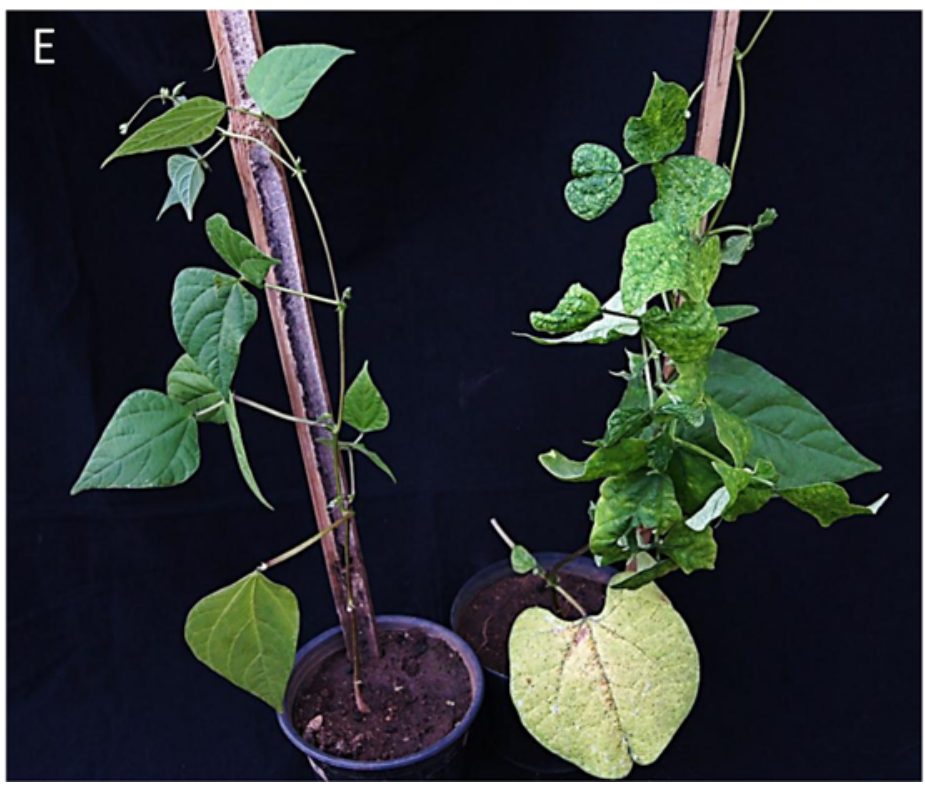

Infected

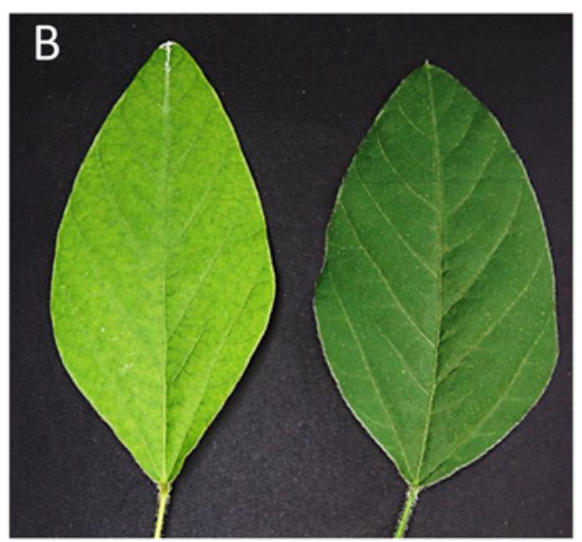

Infected

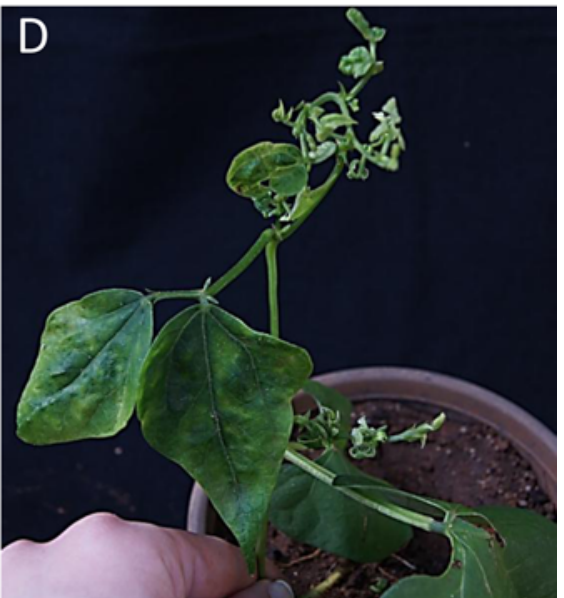

Infected

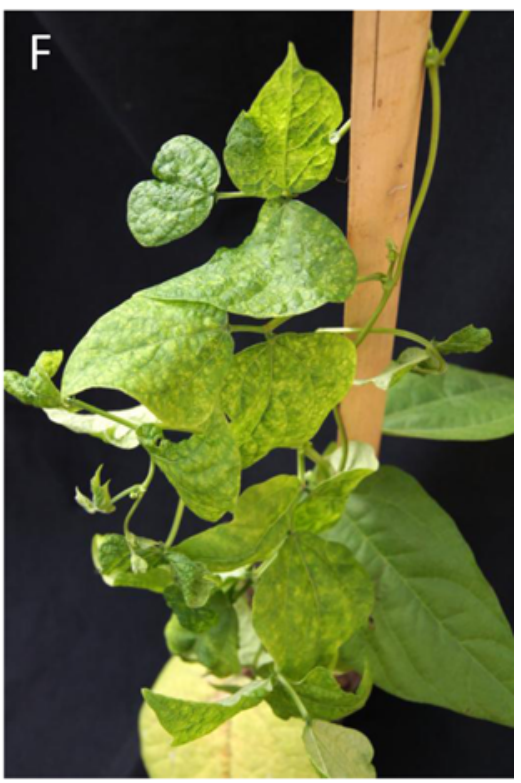

Fig. 2 Symptoms induced by biolistic inoculation of infectious SoCSV DNA-A and DNA-B into leguminous crops. Photographs were taken 35-41 days after biolistic inoculation of soybean or bean cotyledons with tandemly repeated copies of SoCSV DNA-A and DNA-B. a and b show the symptoms observed on newly emerging leaves of Glycine max Conquista (a) and G. max Msoy 7908 RR (b). The symptoms displayed by Phaseolus vulgaris 'Pérola' are shown in c and $\mathbf{d}$, and the symptoms caused in P. vulgaris 'Ouro Negro' are shown in $\mathbf{e}$ and $\mathbf{f}$ 
Acknowledgments This research was financially supported through the following grants from Brazilian Government Agencies: CNPq grants 559602/2009-0, 573600/2008-2 and 470287/2011-0 (to E.P.B.F.), FAPEMIG grant CBB-APQ-00070-09, and FINEP grant 01.09.0625.00 (to E.P.B.F.). O.J.B.B. and D.C were supported by CAPES graduate fellowships associated with INCT in Plant-Pest Interactions; I.C. was supported by a CNPq graduate fellowship; A.A.S. was supported by a postdoctoral fellowship from CAPES. A.K.I.N. is a CNPq fellow.

\section{References}

1. Aragão FJL, Faria JC (2009) First transgenic geminivirus resistant plant in the field. Nature Biotechnol 27:1086-1088

2. Arguello-Astorga GR, Guevara-Gonzalez RG, Herrera-Estrella LR, Rivera-Bustamante RF (1994) Geminivirus replication origins have a group-specific organization of iterative elements: a model for replication. Virology 203:90-100

3. Arguello-Astorga GR, Ruiz-Medrano R (2001) An iteron-related domain is associated to Motif 1 in the replication proteins of geminiviruses: identification of potential interacting amino acidbase pairs by a comparative approach. Arch Virol 146:465-485

4. Faria JC, Bezerra IC, Zerbini FM, Ribeiro SG, Lima MF (2000) Current status of geminivirus diseases in Brazil. Fitopatol Bras 25:125-137

5. Faria JC, Maxwell DP (1999) Variability in geminivirus isolates associated with Phaseolus spp. in Brazil. Phytopathology 89:262-268

6. Fauquet CM, Briddon RW, Brown JK et al (2008) Geminivirus strain demarcation and nomenclature. Arch Virol 153:783-821

7. Fernandes FR, Cruz ARR, Faria JC, Zerbini FM, Aragão FJL (2009) Three distinct begomoviruses associated with soybean in central Brazil. Arch Virol 154:1567-1570

8. Fontes EPB, Eagle PA, Sipe PS, Luckow VA, Hanley-Bowdoin L (1994) Interaction between a geminivirus replication protein and origin DNA is essential for viral replication. J Biol Chem 269:8459-8465

9. Fontes EPB, Santos AA, Luz DF, Waclawovsky AJ, Chory J (2004) The geminivirus NSP acts as virulence factor to suppress an innate transmembrane receptor kinase-mediated defense signaling. Gen Dev 18:2545-2556
10. Hanley-Bowdoin L, Settlage SB, Orozco BM, Nagar S, Robertson D (1999) Geminiviruses: models for plant DNA replication, transcription, and cell cycle regulation. Crit Rev Plant Sci 18:71-106

11. Inoue-Nagata AK, Albuquerque LC, Rocha WB, Nagata T (2004) A simple method for cloning the complete begomovirus genome using the bacteriophage Q29 DNA polymerase. J Virol Methods 116:209-211

12. Mello RN, Cotrim MAA, Lopes EF, Moreira AG, Contin FS, Fontes EPB, Almeida AMR, Zerbini FM (2002) Survey of begomoviruses associated with soybean and identification of Sida mottle virus (SiMoV) infecting this crop in Brazil. Virus Rev Res 7(Suppl): 157

13. Orozco BM, Hanley-Bowdoin L (1998) Conserved sequence and structural motifs contribute to the DNA binding and cleavage activities of a geminivirus replication protein. J. Biol. Chem. 273:24448-24456

14. Paprotka T, Metzler V, Jeske H (2010) The first DNA 1-like alpha satellites in association with New World begomoviruses in natural infections. Virology 404:148-157

15. Rodríguez-Pardina PE, Hanada K, Laguna IG, Zerbini FM, Ducasse DA (2010) Molecular characterisation and relative incidence of bean- and soybean-infecting begomoviruses in northwestern Argentina. Ann Appl Biol 158:69-78

16. Rojas MR, Hagen C, Lucas WJ, Gilbertson RL (2005) Exploiting chinks in the plant's armor: evolution and emergence of geminiviruses. Annu Rev Phytopathol 43:361-394

17. Santos AA, Lopes KVG, Apfta JAC, Fontes EPB (2010) NSPinteracting kinase, NIK: a transducer of plant defence signalling. J Exp Bot 61:3839-3845

18. Silva SJC, Castillo-Urquiza GP, Hora-Júnior BT, Assunção IP, Limab GSA, Pio-Ribeiro G, Mizubutia ESG, Zerbini FM (2012) Species diversity, phylogeny and genetic variability of begomovirus populations infecting leguminous weeds in northeastern Brazil. Plant Pathol 61:457-467

19. Vanitharani R, Chellappan P, Fauquet CM (2005) Geminiviruses and RNA silencing. Trends Plant Sci 10:144-151

20. Wang H, Buckley KJ, Yang X, Buchmann RC, Bisaro DM (2005) Adenosine kinase inhibition and suppression of RNA silencing by geminivirus AL2 and L2 proteins. J Virol 79:7410-7418

21. Wyant PS, Strohmeier S, Schäfer B, Krenz Ba, Assunção IP, Lima GSA, Jeske H (2012) Circular DNA genomics (circomics) exemplified for geminiviruses in bean crops and weeds of northeastern Brazil. Virology 427:151-157 